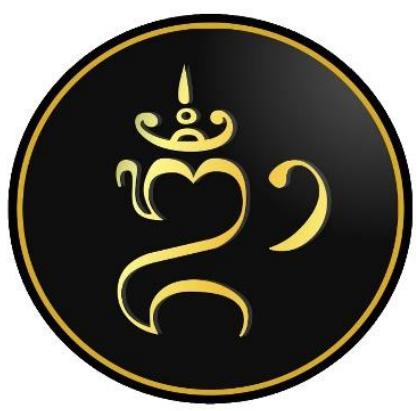

E-ISSN: 2722-8576

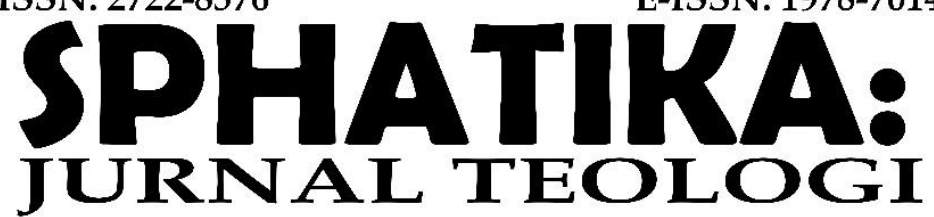

UNIVERSITAS HINDU NEGERI

I GUSTI BAGUS SUGRIWA DENPASAR

VOLUME 12 NOMOR 1, MARET 2021

\title{
BENTUK KERUKUNAN ANTAR UMAT BERAGAMA \\ DI DUSUN KAMPUNG SINDU, DESA SINDUWATI, KECAMATAN SIDEMEN, KABUPATEN KARANGASEM
}

\author{
I Komang Suastika Arimbawa ${ }^{1}$ \\ 1 Universitas Hindu Negeri I Gusti Bagus Sugriwa Denpasar \\ 1suastikaarimbawa@gmail.com
}

\begin{tabular}{l}
\hline \\
\hline Keywords: \\
form; harmony; \\
inter-religious \\
\hline
\end{tabular}

\begin{abstract}
Harmony has become an interesting issue that is discussed in the community, considering that lately many problems have arisen due to intolerance. However, things like that can actually be anticipated, and with a good family, everyone understands the nature of religion in a plural environment. The foundations that can fortify harmony must be, namely the principle of living in harmony and the principle of living with respect. Everyone has an important role to play in maintaining harmony between religious believers. Adaptation is carried out for a common goal, and with a common goal, they mingle with each other regardless of differences, so as to prevent conflicts between religious believers, so that a social order will be realized in society. Thus, members of the community are merged into a social system of society. However, within each one there is still something that is maintained within him, namely the religious principles they adhere to and the norms that they still maintain.
\end{abstract}

\section{Kata kunci:}

antar umat

beragama;

bentuk;

kerukunan

\begin{tabular}{l}
\hline Abstrak \\
\hline Kerukunan telah menjadi isu menarik yang diperbincangkan di \\
tengah masyarakat, mengingat akhir-akhir ini banyak masalah \\
yang timbul akibat perbuatan intoleran. Namun, hal seperti itu \\
sebenarnya dapat diantisipasi, bahkan diselesaikan dengan \\
baik apabila setiap insan memahami hakekat beragama dalam \\
lingkungan plural. Pondasi-pondasi yang dapat membentengi \\
keharmonisan harus diperkuat, yaitu prinsip hidup rukun dan \\
prinsip hidup hormat-menghormati. Setiap orang memiliki \\
peran penting untuk menjaga agar kerukunan antarumat \\
beragama tetap terjalin. Adaptasi dilakukan untuk tujuan \\
bersama, dan dengan adanya tujuan bersama, mereka saling \\
membaur antara yang satu dengan yang lainya tanpa \\
memandang perbedaan yang ada. Upaya ini dilakukan agar \\
dapat mencegah terjadinya konflik antarumat beragama,
\end{tabular}


sehingga terwujud suatu keteraturan sosial dalam kehidupan bermasyarakat. Dengan demikian, anggota masyarakat yang satu dengan yang lainnya melebur dalam suatu sistem sosial masyarakat. Akan tetapi, dalam diri masing-masing tetap ada sesuatu yang dipertahankan, yaitu prinsip agama yang mereka anut serta norma-norma yang tetap mereka jaga.

\section{PENDAHULUAN}

Kehidupan spiritual yang mulai bangkit dalam kehidupan masyarakat merupakan salah satu wajah lain dari era postmodern. Hal ini dapat dilihat dengan meningkatnya minat masyarakat atas ajaran agama. Agama di kalangan masyarakat diyakini dapat mendatangkan rasa aman dan tentram dalam kehidupan manusia, serta dapat mengantarkan umat manusia menuju kebahagiaan hidup jasmani maupun rohani (Arimbawa, 2020: 103). Agama bagi setiap pemeluknya memang merupakan wahyu atau petunjuk Tuhan (revelation). Namun kehidupan beragama merupakan fenomena budaya, artinya manifestasi keberagamaan seseorang mengambil tempat dalam pelataran budaya. Hal ini dikarenakan pikiran manusia berjalan sesuai dengan alur logika bahwa yang beragama adalah manusia, sementara manusia adalah makhluk berbudaya yang tidak mungkin luput dari pengaruh dan jaring-jaring kebudayaan dalam perilakunya. Sebagai implikasinya, maka praktik keberagamaan seseorang atau masyarakat senantiasa melahirkan pengelompokan-pengelompokan (Harahap, 2011: 3). Secara hakekat, agama berperan sebagai pedoman hidup manusia. Setiap agama menghendaki umatnya agar mampu mewujudkan ketentraman dan keharmonisan dalam hidupnya. Agama dalam kehidupan individu berfungsi sebagai suatu sistem nilai yang memuat norma-norma. Secara umum, norma-norma tersebut menjadi kerangka acuan dalam bersikap dan bertingkah laku agar sejalan dengan keyakinan agama yang dianut. Segala bentuk simbol-simbol keagamaan, mukjizat, magis maupun upacara ritual sangat berperan dalam proses pembentukan sistem nilai dalam diri seseorang. Setelah terbentuk, maka seseorang secara serta merta mampu menggunakan sistem nilai dalam memahami, mengevaluasi serta menafsirkan situasi dan pengalaman, artinya bahwa sistem nilai yang dimilikinya terwujud dalam bentuk norma-norma tentang bagaimana sikap diri, dan peran agama dalam memberi pengaruhnya yang paling penting adalah sebagai pembentuk kata hati (conscience). Shaftesbury mengasumsikan kata hati sebagai suatu rasa moral di dalam diri manusia berupa rasa benar dan salah (Jalaluddin, $2012: 318-320$ ). 
Walau demikian, dalam kecenderungan peningkatan kehidupan spiritualitas sering kali dihadapkan dengan keikutsertaan munculnya konflik sosial. Meskipun agama bukan sebagai faktor utama munculnya konflik tersebut, namun dalam eskalasi pemikiran keagamaan seringkali menumbuhkan ideologi keagamaan yang memainkan peranan di dalamnya, sebagaimana dikemukakan oleh Smith (1995) bahwa dunia sekarang sudah mulai memasuki periode krisis yang berlangsung secara terus-menerus. Mereka sudah mulai masuk pada wilayah solidaritas primordial yang merupakan titik lemah dari kehidupan. Kesetiaan umat terhadap agama yang diyakininya cenderung melahirkan ideologi eksklusif yang dapat menimbulkan konflik antarumat beragama.

Keberagamaan dengan ideologi eksklusif akan cenderung melahirkan truth claim, bahwa hanya agama yang dianutnyalah yang benar dan harus diikuti, sedangkan yang lain adalah salah sehingga bisa ditiadakan bahkan yang lebih ekstrem bisa "dibasmi" (Sari \& Arimbawa, 2020 : 197-198). Kenyataan inilah yang mulai menggejala dalam kehidupan keberagamaan layaknya "virus" yang menggerogoti keragaman, seperti terjadinya perusakan dan pembakaran wihara dan kelenteng di Tanjungbalai Sumatera Utara (Sabtu, 30/7/2016). Kejadian tersebut dapat memperparah hubungan antarumat beragama, baik tingkat local bahkan dalam skala global. Selain itu, juga dapat memperlebar jarak sosial, meningkatnya kecurigaan, serta memupuk kebencian antarumat beragama.

Menurut Huntington sebagaimana dikutip Basyir (2013 : 4) menyebutkan bahwa sumber mendasar dari konflik-konflik tampaknya memang memusat pada dua unsur budaya obyektif, yakni etnisitas dan agama. Melalui keduanya, masyarakat saling mengidentifikasi diri dan menjadikan mereka (merasa) berbeda satu sama lain. Dalam situasi tersebut, garis-garis pemisah antar budaya (cultural fault lines) menjadi garis-garis pertentangan yang amat mendasar. Dalam relasi kebudayaan yang penuh ketegangan itulah agama menjadi salah satu unsur pembeda paling determinan.

Konflik yang berlatar belakang agama sebagai perilaku keagamaan yang menyimpang dapat terjadi karena adanya "pemasungan" nilai-nilai ajaran agama itu sendiri, artinya para penganut agama seakan memaksakan nilai-nilai ajaran agama sebagai "label" untuk membenarkan tindakan yang dilakukannya (Arimbawa, $2016: 5$ ). Permasalahan ini akan menjadi semakin kompleks ketika ada kelompok-kelompok radikal yang melakukan tindakan-tindakan kekerasan, pengancaman, penyerangan, dan bahkan pengeboman dengan menggunakan “jubah" agama. 
Pada era postmodern, dimana arus globalisasi semakin meningkat yang dapat dilihat dengan adanya gejala konsumerisme dan hedonisme, kompleksitas permasalahan tersebut seolah-olah menemukan kembali momentumnya. Akibatnya, penganut suatu agama cenderung akan semakin agresif di dalam mencari autentisitas pemikiran keagamaannya, baik dalam memahami agama yang dianutnya maupun agama lainnya. Kejadian ini sebenarnya dapat diantisipasi, bahkan diselesaikan dengan baik apabila setiap insan memahami hakekat beragama dalam lingkungan plural, karena keberagaman sesungguhnya merupakan suatu keindahan yang diciptakan oleh Tuhan.

Pluralitas merupakan sebuah realitas yang tidak dapat diingkari, dan merupakan tantangan utama yang harus dihadapi oleh setiap agama di Indonesia. Kenyataan ini akan membawa konsekuensi logis dalam kehidupan keberagamaan, yaitu tuntutan untuk hidup damai antar keyakinan. Sikap maupun paradigma yang cenderung eksklusif pada akhirnya akan diuji dan dipertaruhkan dalam lingkup multireligius di tengah masyarakat plural, sehingga paradigma yang bersifat inklusif, toleran, bahkan pemahaman keagamaan yang moderat menjadi sebuah solusi atas persoalan yang dihadapi oleh bangsa Indonesia selama ini (Basyir, 2013).

Situasi seperti itulah yang saat ini ada di Bali. Komposisi masyarakat Bali yang semakin plural dan multicultural merupakan modal dasar untuk membangun pola keberagamaan yang akan membawa sebuah tatanan sosial yang dinamis. Fenomena seperti itu terjadi di beberapa tempat di wilayah Bali, salah satunya adalah kampung muslim di Sinduwati (Karangasem). Mereka yang hidup di tengah-tengah masyarakat yang mayoritas Hindu telah mengalami perkembangan yang cukup signifikan, yaitu proses interaksi sosial antar komunitas berjalan dengan harmonis, dan hampir tidak pernah terjadi konflik sebagaimana yang dapat ditemukan di daerah-daerah lain. Situasi harmonis tersebut terjadi karena antar pemeluk agama memiliki kesadaran terhadap hakikat toleransi serta gotong-royong antar sesama. Masyarakat benar-benar menghayati ajaran agamanya masing-masing, sehingga tidak hanya sebatas wacana.

Bali merupakan daerah yang sangat menjunjung tinggi nilai-nilai kerukunan, demikian juga yang nampak pada masyarakat di Dusun Kampung Sindu, Desa Sinduwati, Kecamatan Sidemen, Kabupaten Karangasem, dimana dalam kehidupan sosial masyarakatnya, walaupun hidup dengan perbedaan keyakinan, tetapi mereka mampu untuk tetap saling menghargai (asah), saling menyayangi (asih), dan saling menghormati (asuh). Masyarakat Dusun Kampung Sindu merupakan masyarakat yang 
berbudaya dan memegang teguh adat istiadat secara mendalam (Arimbawa \& Septiari, 2020 : 76). Hal ini terlihat dari pola hidup masyarakat yang masih melaksanakan berbagai rangkaian upacara. Menekuni budaya dan adat istiadat merupakan suatu bentuk cerminan dari proses toleransi yang berelaborasi menjadi kerukunan hidup bermasyarakat.

Salah satu bentuk implementasi kerukunan umat beragama di Dusun Kampung Sindu adalah manyama braya dalam satu tujuan, seperti bersama-sama saling bahumembahu untuk mensukseskan acara keagamaan yang dilakukan. Masyarakat Dusun Kampung Sindu juga dapat menjadi salah satu contoh bagi masyarakat lainnya karena mampu menjalin hubungan yang harmonis dengan yang berbeda agama. Realitas tersebut memiliki keunikan tersendiri, karena fenomena keberagamaan di Indonesia selama ini rentan dengan terjadinya konflik antarumat beragama. Oleh karena itu, kehidupan sosio-religius yang harmonis sebagaimana yang terjadi pada masyarakat multicultural di Dusun Kampung Sindu menjadi fenomena penting dan menarik untuk dijadikan sebagai media pembelajaran bagi kehidupan keberagamaan di daerah lain.

\section{METODE}

Jenis penelitian ini adalah penelitian kualitatif dengan design penelitian terfokus pada field research. Untuk menghindari meluasnya permasalahan yang akan diteliti, maka lokasi penelitian ditetapkan di Dusun Kampung Sindu, Desa Sinduwati, Kecamatan Sidemen, Kabupaten Karangasem, karena berdasarkan pengamatan peneliti di sana walaupun hidup dengan perbedaan keyakinan, tetapi mereka mampu tetap saling menghargai (asah), saling menyayangi (asih), dan saling menghormati (asuh). Jenis data dalam penelitian ini adalah data kualitatif yang diperoleh melalui dua sumber data, yaitu data primer dan data sekunder. Teknik pengumpulan data dilakukan dengan cara observasi, wawancara, studi pustaka, studi dokumen, dan penelusuran data online. Data mentah yang telah dikumpulkan selanjutnya dianalisismelalui tiga tahap kegiatan, yaitu reduksi data, klasifikasi data, dan display data. Kemudian hasilnya disajikan dengan teknik deskriptif.

\section{PEMBAHASAN}

\subsection{Gambaran Umum Desa Sinduwati}

Desa Sinduwati merupakan salah satu dari 10 desa yang ada di Kecamatan Sidemen, Kabupaten Karangasem, Provinsi Bali dengan luas wilayah 329 Ha dengan 
pembagian batas wilayah sebelah utara adalah Desa Selat, sebelah selatan adalah Desa Sidemen, sebelah barat adalah Desa Sangkan Gunung, dan sebelah Timur adalah Desa Manggis. Secara administrasi kepemerintahan, Desa Sinduwati di bagi menjadi 5 (lima) banjar dinas, yaitu: Banjar Dinas Iseh, Banjar Dinas Kikian, Banjar Dinas Sindu Bali, Banjar Dinas Kampung Sindu, dan Banjar Dinas Punia. Selanjutnya secara adat /pakraman, di bagi menjadi 2 (dua), yaitu: Desa Pakraman Iseh dan Desa Pakraman Tabola. Dan secara banjar adat di bagi menjadi 5 (lima), yaitu: Banjar Adat Iseh, Banjar Adat Kikian, Banjar Adat Boan, Banjar Adat Sindu Bali, dan Banjar Adat Punia. Keadaan Topografi Desa Sinduwati terdiri atas dataran tinggi, dengan ketinggian 700 mdpl, yang terdiri dari tanah sawah dan tanah tegalan.

Sesuai dengan registrasi penduduk pada akhir tahun 2018 penduduk Desa Sinduwati berjumlah 5.254 jiwa. Kemudian dalam upaya melaksanakan serta meningkatkan kuantitas dan kualitas pembangunan di Desa Sinduwati, baik secara fisik maupun non fisik perlu didukung prasarana yang memadai. Hal ini diperlukan dalam rangka memperlancar kegiatan pemerintahan, pendidikan, kesehatan, perekonomian, pembangunan dan kemasyarakatan.

\subsubsection{Sejarah Desa Sinduwati}

Pada awalnya Desa Sinduwati berada di bawah Perbekelan Sidemen dengan status kedusunan, kemudian pada tahun 1998 Desa Sidemen dimekarkan menjadi dua desa yaitu Desa Persiapan Telaga Tawang dan Desa Persiapan Sinduwati berdasarkan SK Gubenur Bali Nomor 400 Tahun 1998 tertanggal 18 Agustus 1998 dan SK Bupati Karangasem Nomor 04 Tahun 1998 tertanggal 20 April 1998 dan yang dipergunakan sebagai kantor adalah balai Banjar Sindu Bali serta mulai aktif bekerja pada tanggal 9 Nopember 1998 dan sebagai pejabat kepada desa persiapan pada saat itu adalah I Wayan Puria. Pada tahun 2003 Desa Persiapan Sinduwati menjadi desa dipinitif berdasarkan SK Bupati Karangasem Nomor 99 tahun 2003 tertanggal 26 Maret 2003 yang dipergunakan sebagai kantor sampai saat ini adalah Gedung Kantor Camat Sidemen yang tidak dipergunakan lagi dan sebagai Kepala Wilayah / Pejabat Kepala Desa Sinduwati adalah I Wayan Puria sampai dengan tahun 2004. 


\subsection{Bentuk Kerukunan Umat Beragama di Dusun Kampung Sindu, Desa Sinduwati,}

Kecamatan Sidemen, Kabupaten Karangasem

\subsubsection{Sejarah Komunitas Muslim di Dusun Kampung Sindu, Desa Sinduwati, Kecamatan Sidemen, Kabupaten Karangasem}

1) Munculnya Kerajaan Karangasem dan Penguasaan atas Lombok

Sejarah berdirinya Kampung Sindu tidak bisa dilepaskan dari sejarah Kerajaan Karangasem yang melakukan perluasan wilayah ke Lombok. Bila dilihat secara historis, penguasaan Bali atas Lombok sebenarnya terjadi jauh sebelum kerajaan Karangasem, yaitu sekitar abad XVI oleh kerajaan Gelgel pada era kepemimpinan Dalem Waturenggong.

Setelah Dalem Waturengong meninggal, ia digantikan oleh dua orang putranya, yaitu I Dewa Pemayun yang bergelar Dalem Bekung dan I Dewa Anom Sagening. Karena umurnya yang masih muda, dalam menjalankan pemerintahan didampingi oleh lima orang, yaitu: I Dewa Gedong Arta, I Dewa Anggungan, I Dewa Nusa, I Dewa Bangli, dan I Dewa Pagedangan. Sedangkan jabatan Patih Agung dipegang oleh I Gusti Arya Batanjeruk dan semua kebijakan pemerintahan ada di tangan Patih Agung Batanjeruk. Situasi ini lama kelamaan menimbulkan ketidakpuasan di kalangan pejabat kerajaan. Tampaknya gelagat Batanjeruk untuk mengambil alih kekuasaan telah diketahui oleh penasihat raja Dang Hyang Astapaka. Dang Hyang Astapaka menasihati Batanjeruk agar tidak melakukan hal-hal yang membahayakan, karena pengikut raja cukup kuat. Namun, nasihat Dang Hyang Astapaka tidak dihiraukan oleh Batanjeruk sehingga ia memberontak. Oleh karenanya Batanjeruk kemudian meninggalkan istana Gelgel menuju desa Budakeling yang terletak di daerah Karangasem.

Asal usul raja-raja yang memerintah di Karangasem berawal dari masa Kerajaan Karangasem berada di bawah kekuasaan Kerajaan Gelgel, dan pemerintahan dipegang oleh I Dewa Karangmala yang berkedudukan di Batuaya. Tentang peralihan kekuasaan dari I Dewa Karangmala ke dinasti Batanjeruk, tidak di sebutkan dalam sumber tertulis secara lengkap. Berdasarkan sumber tradisi lisan, setelah berselang beberapa lama dari meninggalnya Batanjeruk, I Dewa Karangmala tertarik kepada janda Batanjeruk yang pada saat itu tinggal di kediaman Dang Hyang Astapaka. Ia ingin meminang sang janda agar mengajukan satu syarat yaitu setelah perkawinannya berlangsung agar I Dewa Karangmala mau mengangkat putranya menjadi penguasa di Karangasem. Permintaannya itu dipenuhi oleh I Dewa Karangmala, sehingga beberapa bulan 
kemudian pemerintahannya diserahkan kepada I Gusti Oka. Mulailah saat itulah penguasa di Karangasem dipegang oleh dinasti Batanjeruk.

I Gusti Oka mempunyai tiga orang istri. Dari ketiga istrinya itu lahirlah enam orang putra. Seorang di antaranya bernama I Gusti Nyoman Karang, lahir dari istrinya yang pangarep, dan dialah yang menggantikan kedudukan ayahnya sebagai raja. Sejak pemerintahan kedua orang raja tersebut, tidak ada sumber yang dapat memberikan keterangan mengenai kegiatan yang mereka lakukan. Baru kemudian setelah pemerintahan I Gusti Anglurah Ktut Karang sebagai raja Karangasem III, tampaknya lebih teratur dari keadaan sebelumnya. Ia diperkirakan sebagi pendiri Puri Amlaraja yang kemudian bernama Puri Kelodan pada pertengahan abad XVII. Ia berputra empat orang, tiga orang laki-laki dan satu orang perempuan. Putranya yang tertua bernama I Gusti Anglurah Wayan Karangasem, I Gusti Anglurah Nengah Karangasem, I Gusti Ayu Nyoman Rai dan I Gusti Anglurah Ketut Karangasem.

Ketika I Gusti Anglurah Ktut Karang mengakhiri masa pemerintahannya, ia menyerahkan kekuasaannya kepada ketiga putranya yang laki-laki untuk memerintah bersama-sama yakni I Gusti Anglurah Made Karang, ia digantikan oleh tiga orang putranya Gusti Anglurah Made Karangasem Sakti yaitu I Gusti Anglurah yaitu I Gusti Anglurah Made Karangasem yang wafat (Dewata) di Pesaren Anyar, Karangasem, I Gusti Anglurah Nyoman Karangasem, Dewata di Bale Ukiran, Karangasem, dan I Gusti Anglurah Ketut Karangasem, Dewata di Petandakan, Karangasem. Sistem pemerintahan secara kolektif ini merupakan hal yang lazim berlaku dalam birokrasi tradisional di Kerajaan Karangasem. Di bawah pemerintahan mereka, Karangasem semakin menanjak. Beberapa faktor penting yang menyebabkan kekuasaan Kerajaan Karangasem semakin meluas: pertama, Kerajaan Gelgel sebagai pusat pemerintahan di Bali yang pada masa pemerintahan Dalem Dimade mengalami kemerosotan. Banyak wilayah kekuasaannya di luar Bali membebaskan diri, sedangkan situasi di dalam negeri terpecah-belah. Kedua, situasi politik di Bali antara tahun 1650-1686 memberikan kesempatan kepada kerajaan-kerajaan yang sebelumnya menjadi taklukkan membebaskan diri yang pusat kerajaannya pindah dari Gelgel ke Klungkung. Kerajaan Karangasem meluaskan kekuasaannya ke timur yaitu Lombok pada tahun 1692, dan membantu Kerajaan Buleleng menaklukkan Blambangan pada tahun 1697. Ketiga, kekuatan spiritual yang bersumber pada kualitas supranatural sang pemimpin, melahirkan tipe kekuasaan yang kharismatik, yaitu kepercayaan yang menghubungkan keturunan raja dengan dewa. Hal ini merupakan suatu keunikan yang dimiliki oleh 
keturunan raja-raja di Kerajaan Karangasem sehingga dapat membawa Kerajaan Karangasem ke puncak kebesarannya.

Seiring perkembangan waktu, Karangasem pada akhirnya kembali berhasil menaklukkan Lombok. Proses penaklukan Karangasem terhadap Lombok berlangsung sejak jatuhnya Kerajaan Seleparang pada tahun 1691-1740, pada tahun 1740 diperkirakan seluruh Kerajaan Lombok sudah dapat dikuasai oleh Kerajaan Karangasem. Setelah berhasil menaklukkan Lombok I Gusti Anglurah Ketut Karangasem kembali pulang ke Bali untuk melaporkan kemenangannya kepada Raja Karangasem Rakanda I Gusti Anglurah Nengah Karangasem. Beliau pulang membawa oleh-oleh tanda kemenangan berupa "bende" (berupa gong) mulanya digunakan sebagai genderang perang oleh Kerajaan Seleparang. Juga dibawa sebuah periuk besar dari tembaga juga berasal dari Kerajaan Seleparang.Ada juga "lelancang" (tempat sirih untuk raja) yang terbuat dari emas asal dari Datuk Pejanggik.

\section{2) Hubungan dengan Komunitas Muslim}

Keberadaan Kampung Sindu di Desa Sinduwati merupakan satu kesatuan dengan Puri Karangasem. Keberadaan kampung-kampung Muslim menempati posisi-posisi tertentu yang mengelilingi puri, secara alami menjadi benteng besar yang digunakan sebagai pertahanan. Masyarakat Muslim Lombok datang ke Karangasem sejak Karangasem menanamkan kekuasaan di Pulau Lombok. Akibat terjalinnya hubungan antara Kerajaan Karangasem dengan Lombok, Orang Sasak secara berangsur-angsur datang ke Karangasem dan kebanyakan dari mereka itu sebagai tetadtadan raja atau sebagai pengiring maupun diangkat sebagai prajurit kerajaan. Penempatan masyarakat Muslim kemudian meluas sampai di Kecamatan Sidemen, tepatnya di Kampung Sindu Desa Sinduwati (Wawancara Tanggal 13 Juni 2020).

Perkembangan masyarakat Muslim diikuti dengan pendirian masjid sebagai tempat shalat yang di pakai setiap hari merupakan bangunan utama selain tempat tinggal. Menurut Maksun, keberadaan bangunan masjid-masjid di Kampung Sindu mengikuti pola penempatan masyarakat Islam yang ada di sana. Masyarakat Muslim di Kampung Sindu juga tidak merasa dirugikan dengan penempatan tersebut karena mendapatkan perhatian dari Puri dan Griya-Griya yang ada di sana (Wawancara Tanggal 15 Juni 2020). 


\subsubsection{Sosial Keagamaan Masyarakat Dusun Kampung Sindu, Desa Sinduwati, Kecamatan Sidemen, Kabupaten Karangasem}

Aspek sosial keagamaan dalam hal ini berupaya meninjau jalinan komunikasi antara umat Islam dengan umat Hindu yang berlangsung dalam kehidupan sehari-hari warga Dusun Kampung Sindu, Desa Sinduwati. Masyarakat Kampung Sindu secara umum dapat dikatakan sangat taat pada agamanya. Namun dalam konteks ini, agama Hindu secara sosiologis menjadi agama mayoritas di Desa Sinduwati. Kehidupan masyarakat di sana tidak dapat dilepaskan dengan nila-nilai yang terkandung dalam ajaran agamanya. Fakta sosiologis ini berlaku di Dusun Kampung Sindu, tetapi keberadaan umat agama lain di wilayah tersebut yang dapat dilihat dari keberadaan tempat sucidua agama (Hindu dan Islam), yang menunjukkan adanya sikap terbuka dan saling menghormati dalam kehidupan masyarakat Dusun Kampung Sindu.

Salah satu bentuk kerukunan antara umat Hindu dan umat Islam di Dusun Kampung Sindu terlihat ketika berlangsungnya acara-acara keagamaan dari masingmasing agama tesebut. Sebagaimana penuturan Hasanuddin yang mengatakan bahwa ketika ada perayaan hari-hari besar keagamaan, seperti Hari Raya Nyepi, Satkam Dusun Kampung Sindu bekerjasama dengan Pecalang setempat untuk menjaga keamanan warganya agar pelaksanaan hari raya tersebut berjalan dengan lancar, demikian juga sebaliknya. Interaksi sosial ini menunjukkan bahwa antara umat Islam dan Hindu sudah terjalin rasa saling menghargai dan menghormati satu sama lain (Wawancara Tanggal 27 Juni 2020).

Senada dengan pernyataan Hasanuddin, Kepala Wilayah Dusun Kampung Sindu juga menyampaikan hal yang sama, yang menunjukkan interaksi antara umat Hindu dan umat Islam hidup rukun. Keadaan seperti itu sudah menjadi kebiasaan yang berlangsung sejak lama. Ia menyebutkan bahwa pihak Griya juga mengundang penduduk setempat ketika ada upacara keagamaan, demikian juga sebaliknya. Pernyataan tersebut menunjukkan bahwa masyarakat Kampung Sindu sudah sangat terbuka dengan perbedaan yang ada, bahkan interaksi demikian sudah menjadi hal lumrah di tengah-tengah kehidupan masyarakat (Wawancara Tanggal 15 Juni 2020).

Bahkan menurut Maksun, tradisi ngejot dilakukan antara umat Islam dan umat Hindu (Wawancara Tanggal 15 Juni 2020). Kesadaran tersebut selain lahir dari masyarakat sendiri memang didukung oleh pemuka agama di Dusun Kampung Sindu. Sebagaimana telah dijelaskan di atas, bahwa pemuka agama bagi masyarakat Sinduwati dan Kampung Sindu khususnya, tidak hanya sekedar menjadi pembimbing dalam 
keagamaan saja, melainkan juga menjadi panutan dalam sopan-santun, serta menjadi rujukan sehari-hari masyarakat dalam berbagai aspek.

\subsubsection{Pondasi Kerukunan Beragama dalam Masyarakat di Dusun Kampung Sindu, Desa Sinduwati, Kecamatan Sidemen, Kabupaten Karangasem \\ 1) Prinsip Hidup Rukun}

Kerukunan berarti sepakat dalam perbedaan-perbedaan yang ada dan menjadikan perbedaan itu sebagai titik tolak untuk membina kehidupan sosial yang saling pengertian serta menerima dengan ketulusan hati. Kerukunan merupakan kondisi dan proses tercipta dan terpeliharanya pola-pola interaksi yang beragam diantara unit-unit yang otonom. Kerukunan mencerminkan hubungan timbal balik yang ditandai oleh sikap saling menerima, saling mempercayai, saling menghormati dan menghargai, serta sikap saling memaknai kebersamaan (Lubis, 2005 : 7-8).

Sebagai makhluk sosial manusia tidak bisa dipisahkan antara yang satu dengan yang lainnya. Hidup berdampingan dengan orang lain merupakan sebuah keharusan dalam tatanan masyarakat. Kemudian dalam tatanan tersebut, setiap orang mempunyai ciri khas dan corak pemikirannya masing-masing. Hal tersebut bisa disebabkan karena pengaruh pendidikan maupun pengalaman yang berbeda-beda pada setiap orang. Aneka keragaman yang menyatu dalam diri seseorang, baik dari suku, budaya, agama, didikan orang tua, bacaan, tontonan, sifat alamiah, dan lain-lainnya melahirkan pribadi yang sama sekali tidak sama antara pribadi yang satu dengan pribadi yang lainnya. Merupakan suatu yang tidak mungkin jika memaksakan dan berharap agar setiap orang bisa mengikuti pikiran dan kemauan pribadi kita. Namun, untuk bergaul dan berinteraksi dengan semua orang yang berbeda sangatlah mungkin untuk dilakukan. Seseorang bisa berharap agar orang lain dapat memahami dirinya, tetapi yang lebih penting adalah bagaimana berusaha untuk memahami orang lain.

Dalam kehidupan sosial, kita diberikan kebebasan untuk bergaul dengan siapa saja, bahkan hal itu dianjurkan untuk saling mengenal antara satu sama lain. Maka mewujudkan kehidupan yang rukun sangat penting dan menjadi tanggungjawab setiap orang. Karena tanpa hal itu, keunikan serta beragam potensi yang bertebaran dalam diri individu akan menjadi bumerang bagi yang lain. Perbedaan yang tidak dikelola dengan baik akan berpotensi menimbulkan kekacauan.

Prinsip kerukunan bertujuan untuk memertahankan masyarakat dalam keadaan yang harmonis (Suseno, 2003 :39). Prinsip kerukunan merupakan manifestasi dari suatu 
tindakan bahwa dalam setiap situasi manusia dituntut sedemikian rupa sehingga tidak menimbulkan konflik, dan menuntut supaya manusia dalam berkata dan membawa diri selalu menunjukkan sikap hormat terhadap orang lain. Prinsip ini mengutamakan ketunggalan dalam pengertian kesatuan, berarti tatanan yang baik, hubungan yang mulus, absensi gangguan. Ini adalah keadaan statis yang tenang dan menyenangkan (Mulder, $2007: 251$ ).

Berlaku rukun dalam masyarakat di Kampung Sindu dapat diperlihatkan dengan bentuk aktivitas gotong royong dalam segala bidang, misalnya untuk kebersihan lingkungan. Sebagai umat beragama dalam konteks ini dihadapkan pada hidup berdampingan dengan pemeluk agama lain ataupun kepercayaan-kepercayan nenek moyang yang masih eksis sampai saat ini, yang mungkin bertentangan dengan apa yang diyakini. Dalam hati mungkin tidak menerima praktik-praktik keagamaan yang dilihat di depan mata yang dianggap tidak sesuai dengan keyakinan kita ataupun gaya hidup yang jauh dari nilai agama dan etika. Namun, itu merupakan suatu kenyataan yang harus kita terima.

\section{2) Prinsip Hidup saling Hormat-Menghormati}

Penerapan prinsip hormat didasarkan pada pandangan bahwa semua hubungan dalam masyarakat teratur secara hierarkis, bahwa keteraturan hierarkis itu bernilai pada dirinya sendiri dan oleh karena itu orang wajib untuk mempertahankannya dan membawa diri sesuai dengannya. Pandangan itu sendiri berdasarkan cita-cita tentang suatu masyarakat yang teratur baik, di mana setiap orang mengenal tempat dan tugasnya dan dengan demikian ikut senantiasa menjaga agar seluruh masyarakat merupakan suatu kesatuan yang selaras. Pada masyarakat Bali, khususnya di Kampung Sindu, sikap yang dianggap bagus dan beradab adalah sikap yang mencakup kelembutan, kehalusan, keanggunan, dan keluwesan. Segala yang halus dipresentasikan dalam tertib yang baik, disempurnakan dengan anggun dan dilaksanakan secara menawan. Hal itu dianggap sebagai budaya pada titik puncaknya. Sikap yang halus ini memperlihatkan penguasaan tingkatan-tingkatan bicara atau Sor Singgih Basa dalam bahasa Bali, kesadaran akan diri sendiri dan orang lain, serta keharusan untuk bertindak halus dan bersahaja. 


\section{PENUTUP}

Eksistensi masyarakat di Dusun Kampung Sindu, Desa Sinduwati, Kecamatan Sidemen, Kabupaten Karangasem diwarnai dengan adanya perbedaan dalam berbagai aspek kehidupan. Ini merupakan suatu realitas yang tidak dapat dihindari. Kerukunan Antar Umat Beragama mengacu pada pondasi yang melatarbelakangi kerukunan di Dusun Kampung Sindu, yaitu prinsip hidup rukun dan prinsip hormat-menghormati. Kedua prinsip ini saling berkaitan satu sama lain. Walaupun kedua prinsip itu menetapkan titik tolaknya sendiri, tetapi masing-masing pihak mempunyai tempat yang diakui, dengan mengetahui bagimana ia harus bersikap untuk membuka relasi terhadap pihak lain, dan untuk menuju pada keselarasan yang bersifat sempurna. Hal ini dapat dilihat dari gotong royong yang dilakukan masyarakat setempat. Budaya Bali sangat berperan sebagai kekuatan terwujudnya kerukunan hidup.

\section{DAFTAR PUSTAKA}

Arimbawa, I. K. S. (2016). Teologi Kerukunan dalam Teks Tutur Jatiswara. Institut Hindu Dharma Negeri Denpasar.

Arimbawa, I. K. S. (2020). Membangun Kerukunan melalui Konsep Esoterisme dalam Teks Tutur Jatiswara (Studi Filsafat Perennial). Sanjiwani: Jurnal Filsafat, 10(2), 7793.

Arimbawa, I. K. S., \& Septiari, P. A. (2020). Teologi Inklusif Untuk Membangun Kerukunan (Analisis Teks Tutur Jatiswara). Sphatika: Jurnal Teologi, 11(1), 68. https://doi.org/10.25078/sp.v11i1.1495

Basyir, K. (2013). Pola Kerukunan antar Umat Islam dan Hindu di Denpasar Bali. Islamica: Jurnal Studi Keislaman, 8(1).

Harahap, S. (2011). Teologi Kerukunan. Prenada Media Group.

Jalaluddin. (2012). Psikologi Agama, Memahami Perilaku dengan Mengaplikasikan PrinsipPrinsip Psikologi. Rajawali Pers.

Lubis, R. (2005). Cetak Biru Peran Agama. Puslitbang.

Mulder, N. (2007). Mistisisme Jawa: Ideologi di Indonesia. LkiS.

Sari, N. L. R., \& Arimbawa, I. K. S. (2020). Pandangan Hindu tentang Pluralisme dalam Kebhinekaan di Indonesia. Sanjiwani: Jurnal Filsafat, 11(2), 193-202.

Smith, H. (1995). Agama-Agama Manusia. Yayasan Obor Indonesia.

Suseno, F. M. (2003). Etika Jawa: Sebuah Analisa Falsafi tentang Kebijaksanaan Hidup Jawa. PT. Gramedia Pustaka Utama. 